\title{
Semantic Structure of Concept «Macht» in German Cultural Studies: Psycholinguistic Aspect
}

\section{Семантична структура концепту «macht» у німецькій лінгвокультурі: психолінгвістичний аспект}

\author{
Olesia Skliarenko \\ Ph.D. in Philology, \\ Assistant Professor
}

\author{
Олеся Скляренко \\ кандидат філологічних наук, \\ доцент
}

E-mail: lesiaskliarenko82@gmail.com
$\quad$ orcid.org/0000-0003-3412-6560

Pereiaslav-Khmelnytskyi

Hrygorii Skovoroda State

Pedagogical University

30, Sukhomlynskogo Str.,

Pereiaslav-Khmelnytskyi,

Kyiv Region, Ukraine, 08401
ДВНЗ «Переяслав-

Хмельницький державний педагогічний університет імені Григорія Сковороди»

$\bowtie$ вул. Сухомлинського, 30, м. Переяслав-Хмельницький, Київська обл., Україна, 08401

Original manuscript received February 25, 2018

Revised manuscript accepted October 09, 2018

\section{ABSTRACT}

The article reveals some peculiarities of semantic structure of concept "MACHT» functioning in German cultural studies. The analyses of lexicographic objectification of the name of the concept "MACHT» has been done, which points to some peculiarities chain in conceptual way of thinking of the studied mental unit in German cultural studies. The given facts let us suggest, that the model of composites forming with derivative element - macht are productive for German lingual environment and point to their semantic actuality and high recurrence of the given mental unit in conceptual world picture. Lexical and semantic connections of concept verbalizator "MACHT» of the lexem "Macht», which were analyzed in the proposed article point to the polisemantic structure of the actual word. Collocational analyses has shown, that semantic 
peculiarities of function of concept "MACHT» are actually in the word, which is its name - "Macht» and are mostly used in connection with attributes and predicates. The collocation quantity with the lexemes proves that there are some actual language collocations, where the analyzed lexeme is used in communicative area. It was established, that among the main verbalizators of the concept "MACHT» phraseological units are rather wide spread. These phraseological units objectivize all maim concept slots, such as "Action", "Object of Power" and "Subject of Power». Besides we have come to conclusion that research of individual word meaning taking into consideration some association words gives the possibility not only to establish the fact of word meaning change but also to analyze the change of individual world picture of German speaking society and give some predictions about negative changes on German political stage.

As a conclusion we may say, that the proposed study establishes, that through semantic, paradigmatic, syntagmatic and phraseological collocations of the concept lexeme "Macht" the whole chain of cognitive characteristics of the mental unit may be actualized. They point to the fact, that these mental units are relevant in German world picture and in the same way of the complete German nation.

Key words: lexeme, semantic, concept, power, German cultural study, attributive and predicative connections.

\section{Inroduction}

The dominating cognitive and discursive paradigm considers language as an important mechanism in reproducing objects of the reality as a part of the man's conceptual system that both produces and uses it. Political power as an important versatile form of relationships is fixed in semiotic sign systems. Consequently, it is fixed by language means of expression and stored as a mental concept in the native speakers' consciousness.

Thus, it is quite relevant to study a semantic structure of the concept «MACHT» in German-speaking linguo-culture, based on the psycho-linguistic aspect, because power relations as one of the key forms of social interactions in society are the focus of humanities and social sciences and are specifically fixed in native speakers' cognitive memory. However, semantic peculiarities of this linguo-cultural concept, as we know, have not been studied psycho-linguistically yet.

Power relationships as a subject of study are not new to science. Philosophical, political, sociological, psychological as well as linguistic 
studies of power resulted in an independent research area - cratology (Halipov, 1999). Power as the subject of linguistic studies is mainly considered in its two aspects: as the language of power (Petrenko, 2007) as well as a mental unit that accumulates the knowledge of some forms of social interactions defined as «power relationships». However, semantic peculiarities of the concept «MACHT» in German linguo-culture and its psycho-linguistic aspect has not been an object of research. Thus, the purpose of the studies is to find out psycho-linguistic peculiarities of semantics of the concept «MACHT» in German-speaking linguo-cultural world picture. The objective is to study semantic peculiarities of power relationships conceptualization in German.

\section{Methods and methodology of the research}

To achieve the purpose of the article we use the dictionary definitions interpretation method for determining a semantic structure of the concept «MACHT», the direct components analysis method and the component analysis method for defining a semantic prototype of the concept «MACHT». To find out psycholinguistic peculiarities of the concept «MACHT» in German linguo-culture we use the subjective definitions method which allows defining new components of the meaning that can affect a person's individual world as a representative of the whole linguo-culture.

\section{Results and Discussion}

The language unit «Macht» acts as a stylistically and emotionally neutral name of the concept «MACHT» in the German language world picture. We consider the lexeme «Macht» to be the basic name of the analyzed concept in the German language world picture. It absolutely meets the requirements for the keyword of the same concept as the most highly used, semantically relevant, stylistically neutral verbal unit (Popova, 2007: 177-178). Lexical and semantic, paradigmatic and syntagmatic aspects of the keyword representing the concept «MACHT» allow us to find the ways power relationships are conceptualized in the conceptual sphere of the German people.

The lexeme «Macht» as a lexical and semantic verbalizer of the concept «MACHT» has a polysemantic structure where different dictionaries list 2 to 5 lexical meanings. The 10-volume Duden dictionary defines the lexeme «Macht» as (Duden, 2018): 1) «a set of 
means and efforts that someone possesses and uses to influence others»; 2) «something that serves as a special, mysterious force or has it»; 3) «politically, socially or publicly related authority status, opportunity or freedom to determine people's behavior or relationships, or to manage them»; 4) «politically and economically powerful state»; «a powerful, influential group or class of individuals»; 5) archaic: «troops, army.» The analyzed lexeme in Duden dictionary is defined, first, according to the source of power of both personal and structural types: «a set of means and powers», «authority, opportunity, freedom»; second, according to the subject of power: «mysterious force», «state», «army»; thirdly, according to the socio-centric result, «an object's behaviour determination». The fifth lexical meaning also presents violence as a method of implementing authority. This dictionary entry focuses on social and non-social spheres of power interactions.

Wahring dictionary (Wahring, 1994) gives two lexical meanings of the word «Macht»: 1) «leadership, dominance, the right to give orders; power, strength, impact force; authority to implement one's will»; 2) «power, force». Both of the above mentioned definitions are not used in the plural. Therefore, in this dictionary the concept's name is primarily associated with sources of power influence (both personal and structural) and self-centered results of these relationships.

According to the electronic dictionary of German of the 20th century (DWDS) the lexeme that verbalizes the concept «MACHT» has four basic meanings (DWDS, 2018): 1) «the rule of people over people», specified by the meanings «a rule of one class over another class or layer, state power» and «an authority to control something or someone»; 2) «power, strength», for example: die Macht des Anpralls, der Wassermassen; die Macht der Liebe, des Glaubens; 3) «politically and economically powerful state»; 4) «a creature or mysterious force created by imagination of a human being». These definitions demonstrate that «power as domination» (Herrschaft) is considered to be the main meaning. According to Duden dictionary, the word «Herrschaft» is defined as «the right and authority to rule somebody». That is the meaning of «power as domination» is conceptualized in connection with existing structural sources as exercising influence. In addition, authority also equals force as an expression of personal sources of power and is similar to its subjects - a mysterious creature and a state. The above 
mentioned definitions include both social and non-social areas where power relationships are implemented.

Bertelsmann dictionary defines the lexeme «Macht» as «a set of means and skills to carry out some personal intentions and / or to rule others or to prevent them from pursuing their plans». This definition succinctly combines both results that are expected from the power: egocentric (fulfilling one's own will) and socio-centric (defining an object's behaviour). The power itself is associated with structural and personal sources that can be found in its subject (Bertelsmann, 1998: 264).

The analysis of the lexicographical objectification of the concept by the lexeme «Macht» indicates a number of features in conceptual understanding of this mental unit in German linguo-culture. Dictionaries show an actualization of the main generic semes of a specific semantic prototype: «Subject of power», «Result», «Resourcefulness of power». Among the specific semes the most relevant are "Causality», «Universality», «Ego-centric result of power» (particularly the seme «Will implementation»), «Socio-centric effect of power» (occasional semes «Manipulative action» and «Restricting influence»), "Sources of power of personal nature» (mainly: Fähigkeit «ability», Kraft «force»), «Structural power source» (primarily: Mittel «means», Befugnisse «authority», Möglichkeit «opportunity», Recht «right»). In addition, we have found an occasional seme of the semantic prototype «Using violence» in the lexical meaning of the word «Macht».

Actual paradigmatic relations (mainly synonyms, antonyms and derivatives) in the name of the analyzed concept of the lexeme «Macht» allow us to determine the ways this mental unit is conceptualized in the German language world picture. This lexeme is commonly found in eight synonymous rows which share similar semantic components. Specifically structured semantic rows show interpretation peculiarities of power relationships in the German worldview.

The modern German language has several synonym-hyperonyms that nominate a subject's general ability to determine an object's behaviour: «Einfluss» («influence»), «Einflussnahme» («influence»), «Einwirkung» («action»), «Wirkung» («action»), «Zusammenwirkung» («interaction»), and stylistically marked synonym-hyperonyms «Botmäßigkeit» («authority»), «Regiment» («authority»). Conceptualization of power relationships in the German linguo-culture depends on a specific type of power influence, according to some certain sub-frames. The power 
in state and political sphere is nominated by the names: «Gewalt» («authority», «violence»), «Herrschaft» («domination»), «Führung» («maintenance, management»), «Staatsmacht» («state power»), «Regentschaft» («management»), «Regierung» («government»), in the military sphere as a part of the state and political subframe they mostly use the words: «Führerschaft» («command»), «Regiment» («power»). Names with a common semantic component «governance, management» are commonly used in the social sphere of relationships: «Anführung», «Leitung», «Verwaltung», «Management».

Synonymous rows of the concept's name for the lexeme «Macht» objectifies the slots in the framing model of the concept «MACHT». The slot «Subject of power» is extended by nominating participants-subjects of power: «Verwaltung» («administration»), «Führung» («officials»), «Leitung» («management»), «Behörde» («executives»), «Regierung» («government»), «Vorstand» («board, presidium»), «Obrigkeit» («leadership»), «Administration» («administration»).

In the synonymous rows the slot «Sources of power» is presented by two merits of the subject of power. The words «Kraft» («strength»), «Stärke» («force»), «Gewalt» («force»), «Können» («skills»), «Vermögen» («ability»), «Wucht» (might), «Fähigkeit» («capacity»), «Power» («force»), «Force» («strength») primarily objectify a subject's physical power. In the German dictionary of synonyms (Bertelsmann, 1998: 427) the slot «Sources of power» is expanded through defining a subject's personal qualities related to its interaction with others in the process of deploying social power relationships. The main qualities include: «Autorität» («authority»), «Durchsetzungsvermögen» («persistence»), «Ausstrahlungskraft» («action strength»), «Charisma» («charisma»), «Wirkungsvermögen» («ability to influence»), «Durchsetzungskraft» («persistence»).

The slot «Structural sources of power» is represented by the following synonyms: «Befugnis» («powers»), «Recht» («right»), «Berechtigung» («right, powers»), «Bevollmächtigung» («powers»), «Ermächtigung» («powers»), «Zuständigkeit» («competence»), «Vollmacht» («commission»), «Befehlsgewalt» («competence»), «Machtposition» («official post») correlating the ability to determine behaviour with an authorized subject's acquired obligations to exercise power. 
Conceptual understanding of the slot «Ego-centric influence of power» and the node «Result of power» is also expanded. In the synonymous row the word «Macht» receives evaluation features, including «Achtung» («attention»), «Ansehen» («respect»), «Prestige» («Prestige»), «Geltung» («significance»), «Gewicht» («importance»), «Autorität» («authority, prestige»), «Ehre» («honour»), «Ruhm» («fame»), «Gnade» («cuteness»), «Massgeblichkeit» («authority») (Deutscher Wortschatz-Portal, 2018), defining power as a significant, prestigious experience that makes a subject a known and socially significant person. Ego-centric use of power is related to the subject's special privileged status found in the synonymous row with the identical seme «superiority, dominance», including: «Dominanz» («domination»), «Allmacht» («almighty») «Hegemonie» («hegemony»), «Vorherrschaft» («domination»), «Vormacht» («domination»), «Vormachtstellung» («dominant position»), «Primat» («primacy»), «Vorrangstellung» («prevailing situation») «Übergewicht» («preferred»), «Überlegenheit» («advantage»), «Oberhoheit» («supremacy»), «Übermacht» («advantage»), «Machtstellung» («positions of power»).

Analysis of synonyms and similarities for the concept makes it possible to define a number of culturally specific aspects for understanding power relationships in the German linguo-culture. First, conceptualization of power is determined by the existence of a significant number of synonyms-hyperonyms within the nominative field of the concept «MACHT». Second, a conceptual understanding of power is achieved through power relationships in certain areas of their distribution, which correlate with sub-frames. These peculiarities prove the fact that the semantic core of the concept «MACHT» lacks unity because of some specific power relationships modification in the German language world picture. It is noteworthy that the conceptualization of power is achieved by expending slots in the framing model of the concept, such slots as «Subject of power», "Sources of power», and «Result of power». Thus, the concept «MACHT» acquires some extra important senses: power is identified with its subject; personal sources of power are presented by physical (strength) and moral (persistence) qualities of its subject; structural sources of power depend on commissions; the result of power is conceptualized primarily through the subject who provides it with social importance and dominance in a society. This correlates with «power over» approach in the scientific world picture. 
Based on the research into antonyms concept's names were supplemented by conceptualization peculiarities of power in the German linguo-culture. The lexeme «Macht» as a keyword of the concept forms a paradigmatic relationships within at least three antonymous rows. First, the word «Macht» is opposed to the antonymous row «Ohnmacht» («helplessness»), «Schwäche» («weak»), «Machtlosigkeit» («helplessness, powerlessness»), «Unmöglichkeit $\mathrm{zu}$ handeln» («inability to act») (Müller, 2000: 346). An antonymous meaning actualizes one of the slots of the analyzed concept «Personal sources of power». In addition, within the antonymous row «Anarchie» («anarchy»), «Durcheinander» («contradiction»), «Gewirr» («mess»), «Konfusion» («confusion»), «Unordnung» («mess»), «Verwirrung» («embarrassment»), «Wirrnis» («confusion»), «Wirrsal» («mess»), «Klüngel» («mess»), «Chaos» («chaos») power relationships are conceptualized by a representative of the German linguo-culture through an expected constructive socio-centric result of the power realization objectified in the slot «Power implementation result». Thirdly, the power conceptualization in the antonymous row is achieved through the subject of power: «Gegenmacht» («competitor»). Thus, antonymic relations of the concept's name objectify power as constructive interaction by identifying power with its subject, and determining personal sources of power.

Analysis of dictionaries for finding out relationships hypohyperonymic of the lexeme «Macht» shows categorial uncertainty and definition complexity of the concept. According to the electronic dictionary of modern German DWDS the lexeme «Macht» is a hyperonym of several lexical and semantic groups (DWDS, 2018). First, the lexeme analyzed is a generic term for the group of words with a common meaning «ability to influence someone or something»: «Machtbefugnis», «Zwang», «Allmacht», «Machtvollkommenheit»; «freedom, independence»: «Volkssouveränität», «Souveränität». The meaning of other lexical-semantic group, the hyperonim of which is the name of the concept «Macht», can be formulated as a «state, political management»: «Militärgewalt», «Polizeigewalt», «Volksmacht», «Sowjetmacht», «Staatsgewalt», «Staatsmacht», «Zentralgewalt», «Gewalt».

Lexicographical sources show that the concept's name denoted by the word «Macht» is a hyponym of notions in two groups: «Herrschaft», 
«Kraft» та «Gruppe», «Wesen». The lexemes «Herrschaft» and «Kraft» activate the semantic meaning «ability, power to influence, to act on someone or something» reflected by the generic seme «Resourceness». Whereas the words «Gruppe» and «Wesen» objectify the seme «Social interaction» which is found in the sectional approach to the concept «power» / «Macht» (DWDS, 2018).

Thus, hypo-hyperonymic connections of the lexeme «Macht» prove that representatives of the German linguo-culture conceptualize power through sources and subject. Power associated occasional signs as a social phenomenon (macro-frame 1) and the use of violence to implement it confirm the importance of «power over» paradigm in mental understanding of power in the studied language world picture.

Analysis of collocations (most frequent combination of certain words in speech) proves that the word «Macht» as the name of the concept is mainly combined with attributes and predicates. Compatibility frequency with certain lexemes shows the speech combinations where the lexeme is used in the analyzed communicative space. According to the electronic dictionary of the University of Leipzig (Deutscher Wortschatz-Portal, 2018) these collocations often (almost half of the cases) indicate a connection between power and a certain subject (seine Macht, ihre Macht), and determine the subject of power (päpstliche Macht, Macht des ..., Macht der ...); they also identify areas of power relationships, the most frequent of which includes: politische Macht (12\%), militärische Macht (3,6\%), wirtschaftliche Macht (3\%); they provide power with qualitative or quantitative characteristics: höhere Macht (2,3\%), wachsende Macht (2,4\%). Predicates mainly relate power relationships with the node «Action». In particular, nearly a quarter of the cases contributes to the actualization of the slot «Obtaining power» (an die Macht kommen (5\%), Macht an sich reißen (4,5\%), sich an die Macht putschen (4,3\%), Macht übernehmen (2\%) etc.). $8.5 \%$ of the cases are objectified through the slot «Power implementation» (Macht haben (6,3\%), an der Macht halten, Macht besitzen, Macht in seinen Händen haben). According to collocations of the concept's keyword, the slot «Object of power» is actualized in 7\% of the cases only.

The concept «MACHT» is also well represented by phraseological units. Phraseologisms verbally objectify all major nodes of the slots «Action», «Object of power» and «Subject of power». Power conceptualization through phraseological units is characterized by the 
use of such nodes of the slot «Action» as: «Need for power» (nach dem Purpur streben), «Obtaining power» (das Heft in die Hand nehmen, das Heft ergreifen / in die Hand nehmen), «Power implementation» (it also includes a cognitive quantitative feature «Having a lot of power»: alle Karten in der Hand haben, am längeren Hebel sitzen, einen langen Arm haben), «Using power», particularly the slot «Power subordinate» (unter seine Botmäßigkeit bringen [zwingen], an der Leine haben, im [in] Bann halten, im Zaume halten), «Losing power» (das Heft aus der Hand reißen [drehen, nehmen], Boden verlieren, jmdm. das Heft aus der Hand nehmen / winden), «Obeying power» (nach j-s. Pfeife tanzen, nach seiner Geige tanzen, unter dem Zepter sein, in Hand stehen), - and the node «Subject of power» (starke Hand, starker Arm).

In addition, the phraseological corpus representing verbalizers of the concept «MACHT» includes a separate cognitive domain, which correlates with the subframe «Power in state and political area». This cognitive area includes such slots as «Obtaining power» (sich zum Herrscher emporschwingen, das Staatsruder ergreifen, die Regierung antreten, zur Regierung kommen); «Implementing power» (die Zügel der Regierung ergreifen, das Zepter führen, das Zepter schwingen, am Staatsruder stehen); «It is inappropriate to use power» (seine Befugnis überschreiten, Begünstigung im Amt); «Subject of power» (die gesetzliche Autorität, öffentliche Hand, der Mann am Staatsruder). Analysis of the concept «MACHT» objectification through phraseological units shows the conceptualization of power within macro-frame «Power as a social interaction».

As for the psycholinguistic aspects of the concept «MACHT» verbalization, we carried out an experiment involving subjective definition method. There were 25 native speakers, 0 refusal, aged 21-25 participants in the experiment who identified the concept «MACHT» as: Autorität - 5, Geld - 4, Kontrolle - 4, Regierung - 3, Egoismus - 2, Gewalt - 2, Korruption - 1 .

Semes ranking based on the brightness index IA (Sternin, 2017: 205) will be as follows:

Autorität - 0,2

Geld - 0,16

Kontrolle - 0,16

Regierung - 0,12

Egoismus - 0,08 
Gewalt - 0,08

Korruption - 0,05

The most frequent response was the answer «Autorität» («authority») 5 and «Kontrolle» («control») 4 associated with the above mentioned slot «Sources of power» and the dictionary meaning «leadership, dominance» (Wahring, 1994).

The conceptual understanding expansion of association was achieved by involving the semes «Geld» («money») та «Korruption» («corruption»), which expanded the scope of the slot «Results of power». It is noteworthy that the dictionary meanings of the analyzed concept «MACHT» in Wahring, DWDS, Duden and Bertelsmann dictionaries do not single out a materialistic side of the lexeme «Macht», so this new feature demonstrates a psychological regeneration of modern German values. The existence of such associations in the field of German linguo-culture demonstrates, to some extent, a distrust of authority, as an instrument of control and regulation, as well as weakening of understanding the concept «Macht» as the main tool of democracy.

\section{Conclusions}

Thus, semantic, paradigmatic, syntagmatic, and phraseological relations of the concept's key name of the lexeme «Macht» can actualize a number of cognitive features on the mental level, which appear to be relevant in the language world picture of the German people. Today's meaning of the lexeme «Macht» is expanding and supplemented with new components related to some political changes in German society and is marked by materialistic units.

Research into individual meanings of words-associations makes it possible not only to see the fact of changes in word meaning but also to analyze some changes in an individual world picture of German society's representatives and show predictions for some negative changes in the current political German-speaking arena.

Perspectives for further research into this issue is comparative studies of how the concept «MACHT» functions in German-speaking and English-speaking picture of the world.

\section{References}

Vinogradova, O.Ye., \& Sternin, I.A. (2016) Psycholingvisticheskiie metody v onisanii semantiki slova [Psycholinguistic methods in description of word semantic]. Voronezh: «Istoki» [in Russian]. 
Gaidutchenko, L.V. (2008). Deryvatsiine pole konzeptu Macht (vlada) v nimezkomovnii kartyni svitu [Derivation area of concept Macht (power) in German world picture]. Problemy semantyky, pragmatyky ta kognityvnoi lingvistyky - Problems of semantics, pragmatics and cognitive linguistics, 13, 74-80 [in Ukrainian].

Petrenko, D.A. (2007). Osobennosti rechevoi kommunikativnoi deiatelnosti v srede politikov Germanii [Peculiarities of communicative speaking activity among German politicians]. Prykladna lingvistyka ta lingvistichni technologii. Applied linguistics and linguistic technologies. Megaling-2006. (pp. 257-270) [in Ukrainian].

Popova, S.D., \& Sternin, I.A. (2007). Kognitivnaia lingvistika [Cognitive Linguistics]. Moscow: AST. Vostok-Zapad [in Russian].

Rudakova, A.V. (2014). Teoreticheskiie i prykladnyie problemy psycholingvisticheskoi leksikografii [Theoretical and applied problems of psycholinguistic lexicography]. Voronezh: «Istoki» [in Russian].

Sternin, I.A., \& Rudakova, A.V. (2011). Psicholingvisticheskoie znacheniie slova $i$ iego opisaniie. Teoreticheskiie problemy [Psycholinguistic meaning of the word and its description. Theoretical problems]. Saarbrücken: LAP Lambert Academic Publishing [in Russian].

Sternin, I.A. (2017). Leksikograficheskoiie predstavleniie psicholingvisticheskogo snacheniia slova [Lexicographic imagination of word psycholinguistic meaning]. Vestnik RUDN. Russkii i inostranyie yasyki I metodika ih prepodavaniia Russian and foreign languages and methodology of their education, 15, 204-214 [in Russian]. doi: 10.22363/2313-2264-2017-15-2-204-214

Khalipov, V.F. (1999). Kratologiia kak Sistema nauk o vlasti: monographiia [Cratology as a science about power]. Moscow: Respublika [in Russian].

Verlagsgruppe Bertelsmann (1993). Bertelsmann Lexikon in 15 Bänden. Gütersloh: Bertelsmann Lexikothek Verlag.

Bertelsmann. Synonymwörterbuch. Sinnverwandte Wörter. (1998). Gütersloh: Bertelsmann Verlag.

Deutscher Wortschatz-Portal. wortschatz.uni-leipzig.de. Retrieved from http://www. wortschatz.uni-leipzig.de

Duden. Das große Wörterbuch der deutschen Sprache. duden.de/woerterbuch. Retrieved from http://www.duden.de/woerterbuch

DWDS: Digitales Wörtebuch der deutschen Sprache. dwds.de/woerterbuch. Retrieved from http:// www.dwds.de/woerterbuch

Hoffman P., Lambon Ralph Matthew A., \& Rogers Timothy T. (2013). Semantic diversity: A measure of semantic ambiguity based on variability in the contextual usage of words. Behavior Research Methods, 45(3), 718-730. doi: 10.3758/ s13428-012-0278-x

Müller, W. (2000). Das Gegenwort-Wörterbuch. Ein Kontrastwörterbuch mit Gebrauchshinweisen. Berlin, New York: Walter de Gruyter

Wahrig. Deutsches Wörterbuch (1994). Gütersloh: Bertelsmann Lexikon Verlag.

\section{АНОТАЦІЯ}

Стаття розглядає особливості семантичної структури функціонування концепту "МАСНТ» у німецькій лінгвокультурі, беручи до уваги його психолінгвістичний аспект. здійснено аналіз лексикографрічної 
Семантична структура кониепту «macht» у німецькій...

об'єктивації назви концепту лексеми "Маcht», яка вказує на ряд особливостей концептуального осмислення досліджуваного ментального утворення в німецькій лінгвокультурі. Наведені у статті факти дозволяють стверджувати, що модель утворення композитів із дериваційним елементом - macht $\epsilon$ продуктивною для німецькомовного лінгвального простору та вказує на семантичну актуальність та високу рекурентність відповідного ментального утворення у концептуальній картині світу. Лексико-семантичні зв'язки вербалізатора концепту "МАCHT» лексеми "Macht», що були проаналізованити у поданій статmі, вказують на полісемантичну структуру відповідного слова. Колокаційний аналіз показав, що семантичні особливості функціонування концепту "МАСНТ» полягають у назві слова "Macht» ma використовуються переважно в сполученні 3 атрибутами та предикатами. Частотність сполучуваності 3 лексемами свідчить про актуальні мовленнєві комбінації, в яких аналізована лексема використовується в комунікативному просторі. Було також встановлено, що серед основних вербалізаторів концепту "МАСНТ» широко представлені також фразеологічні одиниці. У них вербально об'єктивуються всі основні слоти вузлів "Дія», "Об'єкт влади» та "Суб'єкт влади». Окрім того ми довели, що дослідження індивідуальних значень слів-асоціацій дає можливість не лише констатувати певний факт зміни значення слова, а також аналізують зміну індивідуальної картини світу представників німецькомовного соціуму та дають, подекуди, прогнози відносно негативних змін на сучасній політичній німецькомовній арені. Аналіз об'єктивації концепту "МАСНТ» у фразеологічних одиницях вказує на концептуалізацію владних відносин у межах макрофрейму "Влада як суспільна взаємодія». Таким чином автором статmі було доведено, що через семантичні, парадигматичні, синтагматичні, фразеологічні зв'язки ключової назви концепту лексеми «Macht» актуалізується або потенційно може актуалізуватися ряд когнітивних ознак ментального утворення, які виступають релевантними в мовній картині світу німецького народу.

Ключові слова: лексема, семантика, концепт, влада, німецькомовна лінгвокультура, атрибутивні та предикативні зв'язки.

Скляренко Олеся. Семантическая структура концета "macht» в немецкой лингвокультуре: психолингвистический аспект

\section{АННОТАЦИЯ}

Статья рассматривает особенности семантической структуры функционирования концепта "МАСНТ» в немецкой лингвокультуре. Был осуществлён анализ лексикографической объективации названия 
концепта лексемы "Macht», которая указывает на ряд особенностей концептуального осмысления исследуемого ментального образования в немецкой лингвокультуре. Приведенные в статье фракты указывают на то, что модель образования композитов с деривационным элементов macht продуктивен для немецкоязычного лингвального пространства и указывает на семантическую актуальность и высокую рекурентность относительно ментального образования в концептуальной картине мира. Лексико-семантические связи вербализатора концепта "МАСНТ» лексеми "Macht», которые были проанализированы в этой статье указывают на полисемантическую структуру соответствующего слова. Колокационный анализ показал, что семантические особенности функционирования концепта "МАСНТ» лежат в поле названия слова "Macht» и используются преимущественно в сочетании с атрибутами и предикатами. Частота сочетаемости с лексемами свидетельствует об актуальных речевых комбинациях, в которых анализируемая лексема используется в коммуникативном пространстве. Было также установлено, что среди главных вербализаторов концепта "МАСНТ» широко представлены также фразеологические единицы. Они вербально объективируют все основные слоты "Действие», "Объект власти» и «Субъект власти». Кроме того, мы доказали, что исследования индивидуальных значений слов-ассоциаций дает возможность не только констатировать некий факт изменения значения слова, а также анализируют изменения индивидуальной картины мира представителей немецкоязычного социума и дают прогнозы относительно некоторых негативных изменений на современной политической арене Германии. Мы доказали, что с помощью семантических, парадигматических, синтагматических, фразеологических связей ключевого названия концепта лексемы "Macht» актуализируются либо потенциально могут актуализироваться ряд когнитивных признаков ментального образования, которые выступают релевантными в языковой картине мира немецкого народа.

Ключевые слова: лексема, семантика, концепт, власть, немецкоязычная лингвокультура, атрибутивные и предикативные связи. 